\title{
A SZORONGÁSOS TÜNETEGYÜTTES ÉS A TANULMÁNYI ELŐMENETEL ÖSSZEFÜGGÉSEI
}

\author{
Szerző: \\ Sáfrány Judit \\ Eszterházy Károly Egyetem (Magyarország)
}

Szerző e-mail címe:

safrany12@gmail.com

\author{
Lektorok: \\ Mező Ferenc (PhD.) \\ Eszterházy Károly Egyetem (Magyarország) \\ Hanák Zsuzsanna (PhD.) \\ Eszterházy Károly Egyetem (Magyarország)
}

Sáfrány J. (2020). A szorongás tünetegyüttes és a tanulmányi előmenetel összefüggései. Különleges Bánásmód, 6. (2). 59-75. DOI $10.18458 /$ KB.2020.2.59

\begin{abstract}
Absztrakt
Jelen tanulmány célja a szorongás, a szociális készségek, a kognitív képességek és a tanulmányi előmenetel összefüggéseinek vizsgálata. Elővizsgálatként a tervezett 200 fős mintából 10 tanuló (9 és 17 éves kor között) adatainak vizsgálata történik, szekunder adatgyúités formájában. Az elsődleges tapasztalatok szerint a szorongás és a szociális készségek alacsony színvonalának gyakori együttjárása valószínűsíthető, ami a megfelelő fejlesztések mellett is akadályozhatja a tanulmányi előrehaladást. Ebben a gyakori iskolai hiányzásoknak és a túlzott pszichés igénybevételnek jelentős szerepe feltételezhető.
\end{abstract}

Kulcsszavak: szorongás, szociális készség, kognitív képesség, fizikai tünetek, iskolai hiányzás, tanulmányi elómenetel

Diszciplinák: pedagógia, pszichológia

\section{Abstract \\ INTERACTIONS OF ANXIETY DISORDERS AND SCHOOL ACHIEVEMENT}

A recent study has aimed to investigate the relationship between anxiety, social skills, cognitive abilities, and the advancement in education. This is a pilot study intended to analyze the data of 10 students (age of 9 and 17 years) from the planned study of 200 students. The data collection method is secondary. As for the first results, the prevalent correlation of anxiety and low level of social skills is likely to observe. This may impair the success of adequate educational development, due to the frequent school absence and the psychical overload.

Keywords: anxiety, social skills, cognitive abilities, physical symptoms, school absence, advancement in education

Disciplines: pedagogy, psychology 
Az iskolai nevelési-oktatási intézményekben számos gyermek- és ifjúkori pszichés zavar befolyásolhatja a tanulmányi előmenetelt, a tanulók (és közvetve a pedagógusok, szülők) szubjektív jóllétét, a szocializációs folyamatot, illetve az egyéni kognitív fejlődést. A környezet számára explicit szenvedéssel is járó tünetegyüttesek általában kellő figyelmet kapnak a kortársak és a felnőtt személyek (szülők, pedagógusok, szakemberek, stb.) részéről. Ezekben az esetekben a tünetek a tanítás folyamatát, a kiegyensúlyozott kortárs-kortárs valamint felnőtt-gyermek interakciókat látványosan akadályozzák. Ide sorolható kórképek többek között a figyelemhiányos hiperaktivitászavar (BNO F90.0 Az aktivitás és figyelem zavarai (2004), a viselkedés-zavar, az oppozíciós zavar, illetve az agresszivitással szövődő bármilyen mentális zavar. Sok esetben a gyermek számára szubjektív szenvedéssel járó, úgynevezett internalizációs pszichológiai eltérések is állhatnak az agresszív magatartás hátterében. Példaként említhető a gyermekkori depresszió, ahol elsősorban a negatív hangulat, kedvetlenség, motiváció- és energiahiány panaszait tartják számon, azonban az ingerlékenység tünete gyakran áll egy depresszióban szenvedő gyermek/serdülő klinikai képének előterében.

A külvilág számára leggyakrabban nem felismert, rejtve, ezáltal kezelés nélkül maradt pszichés kórképek a szorongásos tünetegyüttesek. A gyermekpszichiátriai/-pszichológiai gyakorlatban számos kivizsgálás eredményeként szorongásos zavar kerül feltárásra az egyébként pedagógiai területen tapasztaltalt problémák hátterében. Több gyermeknél, fiatalnál már az iskolába járás folyamata zavart szenved. Képtelenek kilépni komfortzónájukból, ami eleinte elsődlegesen gyakori szomatikus megbetegedésekben manifesztálódik. A szülők és a pedagógusok ilyenkor a gyenge immunrendszert okolják, és a kezelés is szomatikus irányból érkezik (pl. gyógyszeres terápia, illetve különböző immunerősítők, vitaminkészítmények formájában). Amikor azonban az iskolából való hiányzások száma extrém mértéket kezd ölteni, egyre komoly- abbnak ítélhető a helyzet, és alternatív megoldások felé kezd nyitni a szülő. A pszichológiai segítségkérés azonban nem minden esetben saját megoldáskeresése a családnak. Gyakran a gyermek-jóléti szolgálat közvetítésén keresztül keresik fel a szakembert. Azonban ha már erre a hivatalos eljárásra kerül a sor, számítani lehet egy önmagát bezáró, maladaptív kör kialakulására, és igen nehéz feladat elé áll a gyermek, a szülö, és a szakember egyaránt. A „digitális generáció” gyermekeinél hatványozottan érvényesül ez a folyamat. A tanuló a gyakori iskolai távolmaradások miatt egyre inkább kimarad a kortársak közegéből, tanulmányi eredményeiben is elmaradás történik. A szülő az online kapcsolattartást tartja egy egyedüli lehetőségnek gyermeke és korosztálya tagjai között, ami azonban korlátozás nélkül túlzott mértéket ölt. A szociális élet ezen formája valójában nem nyújt elegendő és megfelelő gyakorlási felületet a fiatal számára, amit a - feltételezhetően eredendően is - alacsonyabb szociális készségekkel rendelkező gyermek érzékel. Ennek következtében nem szívesen tér vissza az iskolai közösségbe, illetve ha mégis adódnak próbálkozások, kudarcélmények érik, így tapasztalatai továbbra is elkerülő magatartásra ösztönzik. A magántanulói rendszer korábbi alternatívája sok tanuló számára átmeneti megoldást jelentett. Ebben a státuszban időt nyerhetett a fiatal, hogy a felismert készségdeficit, illetve a kiváltó vagy társuló pszichés zavarok kezeléséhez professzionális segítséget kapjon. Magában rejtette azonban annak a veszélyét is, hogy a gyermekek motiválatlanná váltak a változással szemben. A kényelmesebb megoldás vonzóbb alternatíva lett számukra: kedvük szerinti időben ébredhettek reggelente, az otthon töltött idő sokuk számára strukturálatlan szórakozással, pihenéssel telt, elkerülhették a mindennapos felelések, dolgozatírások stresszét, illetve az esteleges bullying jelenségtôl is védelmet nyer-tek. Mindeközben legfeljebb a tanulmányi évek előrehaladásában történt megoldás, pszichés státuszuk és szocializációjuk egyre inkább zavarttá, fejlődésben elmaradottá vált. Ezek a gyermekek gyakran a 
pszichés regresszió állapotában stagnáltak, melyet szüleik overprotektív magatartása, a gyermeki önállóságot figyelmen kívül hagyó nevelési attitűdje is konzervált. Aktuálisan is elmondható, hogy utánkövetésük legfeljebb a gyermekpszichiáter számára lehetséges, aki esetleges gyógyszeres kezelésüket kíséri figyelemmel, az érintett fiatalok alulmotiváltsága, illetve a szülók, pedagógusok reményvesztettsége, adott küzdelemben bekövetkező kiégése következtében.

A fentiekben felvázolt pedagógiai-pszichológiai folyamat eredménytelensége alapján a hatékony megoldások lehetetlensége tűnik valószínúnek. Ezt feltételezni azonban elhamarkodott lépés lenne. Létezik hatékony intervenció a szemléltetett problémahelyzetre, azonban komoly szülő-pedagóguspszichológus összefogást igényel. Természetesen a folyamat minél korábbi szakaszában történik a felismerés és a beavatkozás, annál hatékonyabb és gyorsabb eredményre lehet számítani. A prevenció jelentősége kiemelkedóen fontos. A pedagógus kompetenciakörbe tartozó diagnosztikus és „terápiás" munka ígérkezik a leghangsúlyosabbnak a szorongásos zavarok és a szociális készségdeficitek kapcsán. A gyermekek, fiatalok iskolai közösségben, a pedagógusok társaságában töltik idejük legnagyobb részét. A pedagógusok azok a szakemberek, akiknek lehetôsége van a legtöbb információt gyújteni a tanulók egyéni és kollektív tulajdonságairól. Elengedhetetlen tehát, hogy a pedagógusok a szorongásos tünetegyüttesek tekintetében is minél szélesebb körű elméleti és gyakorlati tudásra tegyenek szert.

Jelen tanulmány egy átfogó kutatás elôvizsgálataként szolgál. Célkitũzése a szorongásos tünetek, a szociális készségek színvonala, a kognitív képességek és a tanulmányi előmenetel összefüggéseit egységben látni.

\section{A szorongásos tünetegyüttes}

A gyermekkori pszichés zavarok, jelen esetben a szorongás népegészségügyi jelentőségét több tényező bizonyítja. Határozott hátrányt jelent a gyermek számára, hiszen a fejlődést megzavarja, szenvedést okoz (gyakran mind az érintettnek, mind környezetének), felismerés és kezelés nélkül egyre súlyosbodhat, illetve a felnőttkorra is átnyúlhat (Vetró, 1999). Minden esetben elengedhetetlen, hogy figyelembe vegyük az adott gyermek fejlődési szintjét és szociokulturális miliőjét, hiszen a tünetek adekvát értelmezése csupán így lehetséges. Egy konkrét tünet egy bizonyos életkorban még normálisnak tekinthetô, azonban később fennmaradva, illetve korábban megjelenve kórosnak minősíthető (úgymint például a szeparációs szorongás 8 hónapos korban vagy 5 évesen). A mielóbbi felismerés indoka, hogy a korán induló szorongásos vagy depressziós betegségtörténet kedvezőtlenebb lefolyással hozható összefüggésbe a teljes élettörténetet figyelembe véve. Ezenkívül az ifjúkori rizikómagatartásra fokozottabb kockázatot jelent: drog- vagy alkoholabúzus, felelőtlen szexuális magatartás, szuicid veszély, alacsonyabb iskolai végzettség, valamint fizikai egészségproblémák alakulhatnak ki (Birmaher et al., 1996; Donovan \& Spence, 2000; Kessler et al., 2001; Rao et. al., 1995.).

A gyakoribb előfordulású szorongásos zavarok klinikai pszichológiai szintű felosztását az 1. táblázat mutatja be a DSM-5 diagnosztikus rendszer alapján (DSM-5, 2013).

1. táblázat. Gyakoribb elófordulású szorongásos zavarok (Forrás: DSM-5, 2013)

\begin{tabular}{|l|}
\hline \multicolumn{1}{|c|}{ Szorongásos zavarok típusai } \\
\hline Szeparációs szorongás zavar F93.0 \\
\hline Szelektív mutizmus F94.0 \\
\hline Specifikus fóbia F40.x \\
\hline Szociális szorongás zavar (szociális fóbia)F40.10 \\
\hline Pánik zavar F41.0 \\
\hline Agorafóbia F40.00 \\
\hline Generalizált szorongásos zavar F41.1 \\
\hline
\end{tabular}

A szorongás és a depresszió a leggyakoribb pszichés (akár pszichiátriai szintû) problémák egyike gyermek- és serdülőkorban (Costello, Egger \& Angold, 2005), és együttes előfordulási arányuk 
sokkal nagyobb, mint a véletlen (Angold, Costello \& Erkanli, 1999). Az Egészségügyi Világszervezet (WHO, 2020) aktuális adatai szerint éves szinten a gyermek, ifjúsági és felnőtt populáció $25 \%$-a szenved depressziós vagy szorongásos panaszoktól. A tartós betegszabadságok közel 50\%-a depresszió vagy szorongás tünetegyüttese miatt válik szükségessé. Gazdasági jelentőségét adja a témának továbbá, hogy az Európai Unión belül a hangulatzavarok és a szorongásos zavarok együttes költsége megközelítőleg 170 billió Euró évente. A tanulók pszichés hátterű iskolai hiányzásai kapcsán a dolgozó szülők esetében gyermekápolási díj igénybevétele válik szükségessé. Ennek jelentős gyakorisága egészségügyi vállalást jelentve az államra nézve, mind az egészségügy kapacitásbeli leterheltségét, mind az anyagi forrásokat tekintve. A tanulmányi kudarcok tekintetében az elhúzódó tanulmányok illetve a korai iskolaelhagyás (többnyire végzettség nélkül) szintén előnytelen következményekkel jár egy ország munkaerőpiaci gazdasági helyzetét tekintve.

Korábban a szorongásos zavarok és más hasonló rendellenességek egyetlen nagy kategóriába, az érzelmi zavarok közé tartoztak. Az elmúlt évtizedekben azonban egy másfajta megközelítés vált uralkodóvá: a speciális szorongásos zavarokra és depresszív diszfunkciókra alapozva elkezdtek felvázolni alcsoportokat, melyek a BNO-10-ben (2004) és már a DSM IV-ben (1994) is megjelentek. $\mathrm{Az}$ ilyen típusú precíz diagnosztikai differenciálásnak megvan azonban az a hátránya, hogy egyes gyerekek vagy egyik kategóriába sem illenek bele, vagy több is jellemző rájuk (Goodman \& Scott, 1997). A felmérések szerint a gyermekek és a fiatal felnőttek 4-8 \%-a szenved valamilyen szorongásos zavartól, ami akadályozza a kiegyensúlyozott életvezetésben. A vezető gyermekpszichiátriai zavarok listáján ezzel az aránnyal a második helyet érdemelték ki a szorongásos zavarok, a viselkedéses zavarok mögött, de a hiperaktivitást megelőzve.

A szorongásos zavarok jelentős distresszhez, alacsony színvonalú tanulmányi eredményhez és komorbid társuló mentális és fizikális egészségi problémákhoz vezethetnek (Donovan \& Spence, 2000). A szorongásos zavarok éppúgy, mint a depresszió gyakran krónikussá és ismétlődővé válik, és a komorbiditási mutatók 10-50 \% közé tehetők (Garber, \& Weersing, 2010; Kessler, Avenevoli, \& Merikangas, 2001; Scholten et al., 2013). A genetikai befolyásoltságot illetően bizonyították, hogy a szorongó szülőknek elég nagy valószínűséggel a gyermeke is hasonló problémáról számol be, de kiegészítendō, hogy az utánzás, mint a tanulás alapvető formája közrejátszik az eredményben. Szintén erre a kérdésre keresték a választ az ikervizsgálatok, melyek egy mérsékelt örökölhetőséget állapítottak meg. A környezeti hatások közül a kedvezőtlen életesemények szintén szerepet játszhatnak a szorongás kialakulásában. Akár általános dolgokra is gondolhatunk, mint egy barátság megszakadása, rossz anyagi helyzet a szülők munkanélküliségéből kifolyólag, esetleg a szülők válása. Komoly problémát elsősorban akkor jelenthetnek ezek a ténye-zők, ha sokszor, gyakran és egyszerre jelentkeznek. Ezen az elméleti alapon működik a Paykel-féle Életesemény Kérdőív (Paykel, 1970, in Paykel, 1991), mely 61 itemet felsorakoztatva végez felmérést a vizsgálati személy elmúlt egy évének életeseményei kapcsán. A Tringer és Veér (1977) által módosított magyar adaptáció 64 életeseményt vonultat fel, melyben a kitöltő személy megfogalmazhatja az úgynevezett „objektív skála" segítségével, mennyire tekinti megterhelőnek az adott eseményt egy átlagember számára. Ezt követően - szintén önkitöltés formájában - lehet információt gyüjteni arról, milyen eseményekben volt része a vizsgálati személynek. Ennél objektívebb, - a stresszhatás súlyosságának megfelelően - előre pontszámozott életesemények listáját kínálja fel Holmes és Rahe (1967) Social Readjustment Rating Scale (SRRS) elnevezésű mérőeszköze, melyben szintén a pozitív és negatív események kerülnek felsorolásra.

Több elmélet is azt hangsúlyozza, hogy a szorongás a fenyegetettség érzésének megtapasztalásából fakad. Jó példa erre Bowlby (1973) elképzelése, aki a szorongást az elsődleges kötődési sze- 
mélytôl való szeparáció vagy az azzal való fenyegetettség érzésének következményének látja. Figyelemre méltó azonban Abraham Maslow (1962, 1970) szükséglethierarchia elmélete is a szorongásforrás meghatározása szempontjából 1.ábra).

1. ábra. A Maslow-féle szükséglethierarchia (Forrás: Maslow, 1970 alapján a szerzó)

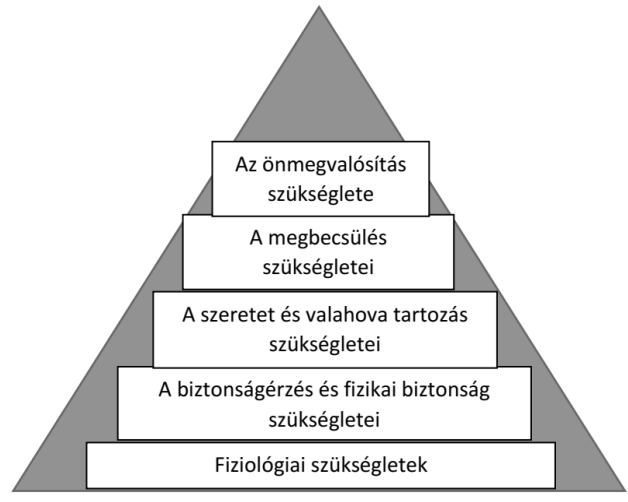

Maslow vizsgálatai szerint az emberi szükségletek hierarchikus rangsorba rendezhetők, és az egyes szükségletek/motivációk különböznek egymástól intenzitásukban, valamint kielégítésük sürgetettségében. A legalsó szinten jelen lévő fiziológiai szükségletek (úgymint például a levegó, a víz, a táplálék) alapvetó fontosságúak az életfenntartáshoz. A biztonságérzet, ezen belül is a fizikai biztonság a szorongás megélésének tekintetében már hangsúlyt érdemel, hiszen ennek szubjektív élménye problémás lehet. Az agorafóbia diagnózisa ezt a kritikus élményt jól magyarázza. Ebben a kórképben az érintett személy bizonyos helyzetekben fenyegetettségérzést tapasztal, ami gyakran a tömegközlekedéssel, nyílt vagy zárt terek megtapasztalásával, valamint a biztonságot adó otthoni környezet egyedül történő elhagyásával lép fel. Az adott szituációval kapcsolatos irreális félelmek a szorongás kialakulásában kulcsfontosságúak, jó példa erre a gyermekkorban gyakran előforduló iskolafóbia, illetve a szociális tér ilyen jellegú minősítése a szociális fóbia. A piramis magasabb szinten elhelyezkedő szükségletei az interperszonális témakörhöz kapcsolódnak. A szociális interakciók következő zónája a szeretet és valahova tartozás. Egy iskoláskorú gyermek illetve fiatal számára az iskolalátogatás és az ott töltött minőségi idő alapvető igénye ez, és súlyos konfliktusforrásokat indíthat el, ha zavart szenved. Mind a diák-diák, mind a diák-pedagógus interakcióknak meghatározó szerepe van az iskolai teljesítményhelyzetek szempontjából. A kölcsönös támogatás, a kiegyensúlyozott társas kapcsolatok megélése mind determinálja a tanulmányi előrehaladást, a mentális kapacitásbeli lehetôségeket. Az a tanuló tehát, aki folytonos személyközi nézeteltéréseket, kudarcokat él meg, kevesebb energiát, idôt tud fordítani a tanulási feladataira, izolálódhat vagy újabb konfliktusokat generálhat a környezetében. A tanult tehetetlenség élménye jól mintázza ezt a jelenséget. Ha egy gyermek megéli azt, hogy bármilyen próbálkozásai legyenek is a társas kapcsolatok rendezésére, ezek sikertelenek, hajlamos lesz arra, hogy elkerülje a kortárs (esetleg tanár-diák) szituációkat, belehelyezkedik a periférián lévő szerepébe, és nem tesz további erőfeszítéseket a megoldásra. Szélsőséges esetben az iskolába járási kötelezettségét is hanyagolni kezdi. Ebből a szintből logikusan következik a megbecsülés szükséglete, melyben a kívülről jövő értékelés és az önértékelés kiemelendő. Az iskolán belüli visszajelző rendszer, valamint az ebból is táplálkozó személyes önértékelés a tanuló személyes hatékonyságának érzését képes fokozni vagy éppen csökkenteni. A pedagógus szerepe ebból a perspektívából rendkívül meghatározó, ugyanis egy gyermek/fiatal bizonyos tulajdonságainak elismerése, pozitív értékelése pszichológiai szempontból önbeteljesító jóslatként múködik. A visszajelzés az értékelt személy figyelmét értékes vonására fókuszálja, ezáltal tudatosabban kezdi el alkalmazni adott képességét. Ezzel nagyobb teret kap a fejlesztés, az önfejlesztés, ami további fejlődésnek adhat alapot. Végül Maslow az emberi motivációk közül az önmegvalósítás szükségletét emelte a legmagasabb szintre. Ez a szint képességeink legteljesebb mértékű megvalósitását jelenti, tehát a nevelés-oktatás cé- 
lkitúzésével analóg gondolatmenet. Összességében azonban a környezeti faktorok mellett a temperamentum kérdése is a szorongás, hiszen a veleszületetten félénk, visszahúzódó gyerekeknél nagyobb a kockázata szorongásos zavar kialakulásának (Goodman \& Scott, 1997).

\section{A leggyakoribb szorongásos zavarok}

Korábban három fő szorongásos zavar említésével lehetett találkozni a leggyakrabban: specifikus fóbiák, szeparációs szorongásos zavar és generalizált szorongásos zavar. Azonban hasonlóan szorongással társuló tünetegyüttesként tartható számon a poszttraumás stressz szindróma, a pánikés elkerülési zavar, amik szintén gyakori prevalenciát mutatnak.

A szeparációs szorongásos zavar már egészen fiatal korban megjelenhet, a gyerekek 1-2\%-ánál fordul elő, inkább prepubertás, mint serdülőkorban. A szorongó gyermek túlzottan fél attól, hogy szülei elhagyják vagy el fog veszni, esetleg idegenek elrabolják, emellett rémálmok is megzavarhatják az éjszakai pihenést. A szülőtől való külön alvás is zavart szenvedhet, ezzel kapcsolatos tapasztalat, hogy a sötétben egyedül tartózkodás során percepziózavarra emlékeztető tünetek léphetnek fel. Az elválási félelem a szülőnek megfelelő kötődési személlyel szemben is fennállhat. Akkor diagnosztizálható a probléma, ha a szorongás mértéke nem reális, következtében csökkennek a gyermek társas készségei, például nem mer iskolába menni, illetve más helyen (pl. nagyszülőnél, táborban) aludni, izolálódik a kortársaitól, de akár a családon belül is. Sok esetben észlelhető, hogy az elsődleges kötődési személyhez való tapadás az otthonon belül is fennáll, és szinte árnyékként követi a „biztonság forrását". Gyakori, hogy a félelem tárgya a szülő vélt betegségének, sérülésének vagy halálának anticipálása, esetleg katasztrófa bekövetkezésének veszélye. A szeparáció lehetősége ellenállást vált ki belőle, ami sírásban, szomatikus tünetek produkálásában nyilvánulhat meg (fej- és hasfájás, hányinger, stb.) (Nagy, 2015). A szülő elvesztésétől való rettegést mintázza az a gyakorlati példa, amikor a szülő saját egészségi állapotával kapcsolatos aggodalma csak részleges formában jut el a gyermekhez, aki a hiányzó részleteket saját fantáziájának segítségével tölti ki. Ez az információpótlás sokszor súlyosabb helyzetet vázol fel, mint a valós probléma, és tartós szorongásforrássá válhat a gyermek számára, ha nem kap mielőbb reális magyarázatot a szülő tényleges egészségi állapotával kapcsolatban - természetesen életkorának megfelelően.

A tanulmány szempontjából fontos észrevétel, hogy a gyermekkori szorongásos tünetegyüttesek közül a szeparációs szorongásos zavar az egyik leggyakoribb, amivel a pszichiáter, pszichológus szakember találkozik. Ennek oka, hogy a megnövekedett számú iskolai hiányzás miatt gyermekvédelmi intézkedés válhat szükségessé, melyben a szülőt kötelezik, hogy professzionális segítséget kérjen a probléma megoldásához (Nagy, 2015).

A szelektív mutizmus az egyéb említett szorongásos zavarok közül ritkábban fordul elő. A klinikai kép előterében áll, hogy az egyébként intakt nyelvi készségekkel rendelkező, verbális kommunikációra képes gyermek megtagadja a beszédet az otthontól eltérô környezetben. Ez jelentős funkcióromlást idéz elő: a kortárs és a családon kívüli környezetben gátoltság, izoláció tapasztalható, a pedagógiai munkában többnyire csak írásbeli számonkérési lehetőség adódik, illetve a gyermek tanulmányi kibontakozása, személyiség- és szociális készségeinek fejlődése mérsékeltté válik.

A specifikus fóbiák a gyermekek és serdülők 1\%át veszélyeztetik. Speciális fóbiává akkor alakul a félelem, ha jelentős distresszel illetve elkerülő magatartással társul, és akadályozza a normális életvitelt. Elsődlegesen akkor okoz komoly funkciózavart a fóbia, ha a félelem tárgyával való találkozás elkerülhetetlen (Nagy, 2015). Ilyen típusú fóbia az étellel, evéssel szembeni averzió, ami például hányásfóbiában manifesztálódhat. A gyakorlatban ennek a folyamatnak az első lépéseként az egyébként egészségszorongásra hajlamos gyermek egyre többször kerüli el az iskolai közegben 
történő étkezést - ezáltal a jövendőbeli hányás veszélyét késlelteti. Errôl a szülő általában a hazakerülő tízóraik alapján szerez tudomást, és a pedagógus megerősítheti az információt, mely szerint a fiatal táplálékbevitele iskolaidő alatt egyre jelentéktelenebb. A hiányos energiamennyiség a 7-8 órás napközbeni idôintervallumban korán megmutatkozik: az érintett gyermek gyengének érzi magát, közérzete rosszabb, így szubjektív is egyre erősebb diszkomfortérzést él át, ami a kondicionálási mechanizmuson keresztül az iskolához kapcsolódik. Ennek következményeként egyre kevésbé vágyik az iskolában töltött időre, és amikor csak teheti, távol marad. Előrevetített szorongása a stressz fiziológiás tüneteit is fokozhatja a reggeli indulás idején, ami hányingerig, hányásig fokozódhat. Máris kialakult egy pszichés alapú ördögi kör, ami az egyébként tehetséges gyermek tanulmányi elörehaladását is hátráltathatja.

A szociális szorongásos zavar, másnéven szociális fóbia kifejezetten olyan helyzetekhez társuló félelmi reakció, amikor más személyek elôtt kell megszólalni, ismeretlen emberekkel történik találkozás, esetleg mások jelenlétében zajlik az étkezés. A teljesítményhelyzetben szükséges megnyilvánulás még inkább fokozza a szorongásélményt (Nagy, 2015). A megszégyenülés kockázata miatt a tipikus szociális, a társas figyelemfókusszal járó helyzetekkel szembeni elkerülő magatartás alakul ki. Kifejezetten a szorongás vegetatív jelei - mint például elpirulás, verejtékezés, elhaló hangerő - jelentkezhetnek a beszélgetéssel járó helyzetekben, ami további szégyenérzést vált ki az érintett gyermekből, így újabb elkerülési mechanizmusok generálódnak viselkedésében (Nagy, 2015).

Pánikzavarral a prepubertás kor előtt szinte alig találkozni professzionális területen. Fiatalabb gyermekkorban inkább a probléma pszichés alapmechanizmusát adó fiziológiás stresszreakciókkal találkoznak időnként a szakemberek. A pánikzavar diagnózisának kritériuma a rekurrens, váratlanul kialakuló, szenvedést keltő szubjektív félelemmel és szomatikus reakciókkal járó pánikrohamok. Akár már az első pánikrohamot követően, majd folyam- atosan jellemző az anticipált szorongás egy következő roham bekövetkezésével kapcsolatban, és ennek „kezelésére” elkerülési, biztonságkereső mechanizmusok aktiválódnak (Nagy, 2015). Általában az első pánikroham helyszíne, körülményei (pl. tömeg és/vagy erős napsütés) negatív megítéléssel kondicionálódnak, és az otthonról való kimozdulás, az iskolába járás, a teljesítményszituációk, ezáltal az általános fejlődés lehetősége akadályba ütközik.

Ahogyan a Maslow-féle szükséglethierarchiában, ezen belül a fizikai biztonság megélésének motivációjánál említésre került, bizonyos helyzetekkel szembeni erős szorongás az agorafóbia. Két formáját különböztethetjük meg a fent bemutatott pánikzavarral való összefüggés alapján: pánikrohamokkal vagy anélkül való megjelenés. A kritikus helyzetek közül minimum kétféle szükséges a diagnózis igazolásához: például tömegközlekedés, otthonról történő kimozdulás egyedül, nyílt (hídon lenni) vagy zárt tér, nagyobb tömeg jelenléte, sorban állás. A félelem fókusza ezekben a szituációkban, hogy pánikroham alakul ki vagy kínos élményben lesz részük (Nagy, 2015). A szomatizációs tünetképzések közül az irritábilis bélszindróma az utóbbi félelmet tisztán mintázza: a (szubjektív) kontrollálhatatlan tünet miatt megszégyenülnek, és emiatt egyre kevésbé mozdulnak ki a biztonságot jelentő otthoni környezetből. Az izoláció miatt számos funkció zavart szenved, úgymint a kortárs közösségben való perifériára kerülés következményei, így még inkább elkerülés tárgyává válik a külső környezet.

Generalizált szorongás esetén jellemző egyfajta állandó, diffúz, fókusz nélküli aggodalom. Általában a jövő vagy múltbeli események miatt aggódnak az érintett személyek, esetleg kompetenciájukat vonják kétségbe, megjelenésükkel kapcsolatban vannak félelmeik. A tünetek mellé társulhat feszültség, a lazításra való képtelenség, állandó megerősítésre, bátorításra való igény, továbbá szomatizálás (például fejfájás, gyomorpanaszok, akár a már említett irritábilis bélszindróma, izomfeszülés, fáradékonyság). Mivel a szorongás „szabadon lebeg”, az előző zavaroknál 
jellemző elkerülő mechanizmus nem hatékony. Gyermekeknél ez a diagnózis tiszta formájában igen ritka (Nagy, 2015).

\section{A szorongás kialakulásának további le-} hetséges magyarázatai

Néhányan próbálkoztak azzal, hogy a depresszió és a szorongás közös genetikai hátterét feltárják. A magas komorbiditás mögött azt találták, hogy a depressziót és a szorongást nagyrészt ugyanazok a gének okozzák (Eley \& Stevenson, 1999). Egy ilyen tanulmány Zavos és munkatársai (2010) nevéhez köthetô, akik azt találták, hogy mind a szorongás, mind a depresszió összefügg a kognitív torzításokkal, úgymint a szorongásos szenzitivitással és az attribúciós stílussal. Habár a szorongást és a depressziót meghatározó gének között lényeges átfedés van, nem mondható ez el a kognitív torzításokkal kapcsolatos genetikai tényezőkről. Német serdülők körében végzett vizsgálatok feltárták a szorongásos zavarok időbeli stabilitását (Essau, Conradt \& Petermann, 2002). Azok a vizsgálati személyek, akik az első vizsgálati idôpontban megfeleltek a DSM-IV-ben (1994) fellelhetô bármely típusú szorongásos zavar kritériumainak, a második vizsgálat idején továbbra is szenvedtek a szorongásos zavar tüneteitől. A szorongás tartósságával a következő tényezők álltak kapcsolatban: idősebb kor, szomatoform vagy szerhasználati zavar jelenléte, valamint nagyszámú negatív életesemény az első vizsgálat idején.

A szorongásos zavarok okát és kimenetét tekintve a felnőttekkel végzett vizsgálatokból származó ismeretek (Keller, Lavori, Wunder, Beardslee, Schwartz \& Roth, 1992) felhívták arra a figyelmet, hogy a legtöbb szorongásos zavar korán indul, általában gyermek- vagy korai serdülőkorban. $\mathrm{Az}$ élet kezdeti szakaszában induló szorongásos zavar gyakran összekapcsolódik más pszichiátriai zavarok kialakulásával és kapcsolatban áll a felnőttkorban különböző életterületeken elszenvedett pszichoszociális sérülésekkel (Wittchen, Essau \& Krieg, 1991). Néhány tanulmány krónikus okokról és alacsony gyógyulási arányról beszél, míg mások (pl. Keller et al., 1992) kedvezőbb kimenetet találtak. A szeparációs szorongásos zavar mutatta a legmagasabb remissziós arányt (96\%), míg a pánikzavar a legalacsonyabbat (70\%). Last, Hansen és Franco (1997) a pszichoszociális múködést vizsgálták fiatal felnőtteknél, akiknél korán kialakult a szorongásos zavar. Azok, akiknek nem voltak társtüneteik (pl. komorbid depresszió), a legtöbb területen hasonlóan múködtek, mint a kontrollcsoport tagjai. Kivételt képezett ez alól az átmenet az önálló életbe, mert a szülőktől elválasztva problémák léptek fel, gondot okozott a „családi fészekből való kirepülés". Azok, akiknél a szorongásos zavar depresszív tünetekkel társult, sokkal nehezebben boldogultak fiatal felnőttként.

A szorongásos zavarok mind tiszta formában, mind más pszichiátriai zavarokkal együtt járva, előrejelzik a szerfüggóséget, az alkohol- és droghasználatot (Lopez, Turner \& Saavedra, 2005). Néhány tanulmánynak sikerült kimutatnia, hogy a szorongásos zavar serdülőkorban nagyobb kockázatot jelent a szerhasználati zavarok tekintetében (pl. Stowell, 1991), míg másoknak nem sikerült dokumentálni az összefüggést (Biederman, Wilens, Mick, Faraone, Weber \& Curtis, 1997). Legelterjedtebben három kiemelkedő nézőpont létezik arra vonatkozóan, milyen kapcsolat van a szorongásos és a szerhasználati zavarok között (pl. Kushner, Abrams \& Borchardt, 2000):

- Az öngyógyító hipotézis („self-medication hypothesis") (pl. Mirin \& Weiss, 1991) szerint ok-okozati kapcsolat vezet a szorongásos zavartól a szerhasználati zavarhoz, mivel az egyének néha azért fogyasztanak alkoholt és/vagy drogokat, hogy enyhítsék a szorongásos tüneteiket.

- Az előbbivel ellentétes szemlélet, hogy a szerhasználati zavar vezet szorongásos zavarhoz, mivel a szerhasználat elősegítheti a szorongásos tünetek kialakulását, mint biopszicho-szociális következményét a krónikus szerhasználatnak (pl. George, Nutt, Dwyer \& Linnoila, 1990). 
- A harmadik szemlélet értelmében nincs okokozati összefüggés a szerhasználat és a szorongásos zavarok között, sokkal inkább egy harmadik változó befolyásolja őket, mint pl. a genetikai prediszpozíció (pl. McGue, 1994). A szorongásos zavarok időben történő felismerésének és kezelésének fontosságára hívja fel a figyelmet az az eredmény, hogy a serdülőkorban jelenlévő szorongásos zavar két-háromszorosára emelte a rizikóját a felnőttkori szorongásnak (Pine, Cohen, Gurley, Brook \& Ma, 1998).

\section{Krónikus stressz és immunfunkciók}

A stresszhatásokkal összefüggő vizsgálatok az egyének közötti eltéréseket vizsgálták stresszt jelentő szituációkban adott reakciók alapján. A „fight or flight” („,küzdj vagy menekülj”) (Cannon, 1929), illetve a „freeze” („,megdermedés”) mint lehetséges viselkedéses válaszok tapasztalhatók az egyén számára kritikusnak megélt „veszélyhelyzetek” tekintetében. Figyelemreméltó eredménye azonban a stresszel kapcsolatos kutatásoknak, hogy a stresszre adott válaszok nem csak viselkedéses szinten jellegzetesek, hanem az immunfunkciók tekintetében is történik változás. A stressz immunmúködést befolyásoló hatása már korábban is felkeltette a kutatók érdeklődését (pl. Irwin et al., 1990). Az akut, tehát rövidebb időtartamú (órák, esetleg napok) stresszhatások rövid erőteljes kortizol (stresszhormon) hiperszekréciót eredményeznek. Ennek hatására a szervezet védekező rendszere aktiválódik, tehát adaptív a hatás. Azonban ha elhúzódó, vagyis közepes intenzitású kortizol hiperszekréció zajlik le hetekig, hónapokig, esetleg évekig elhúzódó stresszhatás következtében, immundeficienciát, tehát a szervezet csökkent ellenálló képességét váltja ki. (Purebl, 2016). Ezzel az élettani jelenséggel is magyarázható, miért olyan gyakran betegek és miért növekszik meg a tartósan elhúzódó stresszhatást átélt tanulók iskolai hiányzásának száma.

\section{Evolúciós előnyök a szorongás hátterében}

Az evolúciós pszichológia a szorongásos reakciók funkcióját, az emberi viselkedésben betöltött „szerepét” igyekszik megmagyarázni. Feltételezi, hogy a háttérben olyan evolúciós stratégiák állnak, amelyek bizonyos szempontból adaptívak, vagy az emberi egyedfejlődés során adaptívak voltak (Gilbert, 1998; McGuire \& Troisi, 1998). Jó példa erre a szubjektív szenvedés- és fájdalomérzet, ami az evolúciós magyarázat szempontjából azért jöhetett létre, hogy az ember figyelmét ráirányítsa az élő és élettelen környezet káros hatásaira, s arra ösztönözzék, hogy az elkerülést válassza (Nesse, 1990). A félelem szempontjából hasonlóan előnyös, ha a külvilág ártalmas ingereire felhívja a figyelmünket, és megtanuljuk ezeket elkerülni vagy felkészülünk a velük való megküzdésre.

Ha azonban a félelmi reakció már eltúlzott és káros, azokban az esetekben is jelen van, amikor valódi veszélyről nem beszélhetünk. Nesse (1999) magyarázata értelmében az ilyen alacsony küszöbértékre beállított védekező rendszerek már akár jelentéktelen intenzitású, semleges ingerekre is aktiválódhatnak.

Az ősember idején a korai adaptációs környezetben a ragadozóval való találkozás „költsége” (a támadás életveszélye) értelemszerúen nagyobb volt, mint a veszélytelen ingerekre adott felesleges reakciók költsége. Így azok az egyedek, akik eredményes ingerfelismeréssel rendelkeztek, nagyobb eséllyel éltek túl, mint társaik. Könnyen érthetővé teszi ezt a védelmi mechanizmust az úgynevezett füstjelző-analógia (Beck \& Emery, 1999). A tűz akkora károkat képes okozni, hogy a túlérzékenyített vagyis alacsony észlelési küszöbbel rendelkező jelzőrendszer biztosít valódi biztonságot. Azonban a gyakori téves riasztás, vagyis az irreális félelmek (pl.állandó félelem a közlekedési balestektől) egyenrangúsítása a reális félelmekkel (pl.medvetámadás) állandó pszichés készenlétet eredményez, túl sok kapacitásunkat veszi igénybe, illetve indokolatlanul kifáraszt. A pánikzavar tipikus megnyilvánulása ennek a szélsőséges formában múködő védekezési rendszernek, amit bizonyít, 
hogy a sürgősségi osztályok betegfelvételénél gyakran találkozni ezzel a pszichés zavarral.

$\mathrm{A} z$ agorafóbia esetében őseink félelme a magára maradástól és az idegenek közeledésétől ma eltúlzott formában nyilvánul meg (Nesse, 1987). Jellemző a fóbiák esetében bizonyos értelemben vett ingergeneralizáció is, vagyis azonos agyi régiókat hasonló környezeti ingerek aktiválnak. A repüléstôl való félelem a szakadékoktól és a kicsi zárt terektől való ôsi félelmünkből fejlődhetett ki (Bereczkei, 2003).

Az egyén túlélését bizonyos veleszületett reflexek is támogatják. Ilyen többek között az úgynevezett „vizuális szakadék reflex” (Marks, 1969). Egy szakadék széléhez közelítve az ember (és számos emlősállat kicsinye) fizikai gátlással reagál, tehát mozdulatlanná válik. Ez az eredendően természetes gátló reakció sok esetben felnőttkorra is átöröklődik, és szédülést is okozhat. Ennek értelmében a gyermekkorban előforduló félelmek (zuhanástól, sérüléstőll, sötétségtôl, mély víztől, stb.) alapvetően adaptívak, hiszen azt a célt szolgálják, hogy a még támogatásra, felvigyázásra szoruló gyermek ne kerüljön olyan helyzetbe, ami számára idegen és veszélyes, ebből következően még nem rendelkezik a megküzdéshez szükséges képességekkel és tudással. Tipikus példa erre a szeparációs félelem (Beck \& Emery, 1999).

A teljesítmény- illetve szereplési helyzetekben gyakran előforduló lámpaláz a negatív értékeléstől való félelemmel függ össze (Beck \& Emery, 1999), és előrevetíti, hogy az egyén hátrányos helyzetbe kerülhet az interperszonális közegben, mások felől korlátozott erőforrásokhoz juthat csak hozzá. Evolúciós értelmezésben ez a túlélési esélyeit csökkentené. Fizikai megnyilvánulásában ez annyit jelent, hogy az anticipált szorongás már sebezhetó állapotot vált ki, a beszédet és cselekvést gátló mechanizmusok pedig "megakadályozzák” a rizikós, „meggondolatlan” viselkedést. Az agorafóbia összetettebb félelmekkel jellemezhetô, egy belső katasztrófa anticipált képzetéhez kapcsolódóan. Ilyen a megőrüléstől, a kontrollvesztéstől, a szívinfarktustól való félelem. Ezt a félelemérzést az képes növelni, ha a támogatást, biztonságot jelentő személyek nem elérhetőek az egyén számára, mivel saját elképzelése szerint egyedül nem képes a megküzdésre (Beck \& Emery, 1999).

Végül a szorongások és a megküzdés sikertelensége kapcsán fontos figyelembe venni, hogy ha irreális, tehát nem egy valódi, jelenlévő vagy eltúlzott veszély indítja el a vészreakciót, az érintett személynek nincs lehetősége az elhárításra (Beck \& Emery, 1999). Ez a kontrollhiány további frusztrációt kelt, és állandósulhat a biztonsághiány, a tehetetlenség élménye, ami a depresszióra rizikótényezôt jelent.

\section{Az OXIPO-modell és a szorongás}

Ha végigvisszük az OxIPO-modell interdiszciplináris (jelen esetben pedagógiai-pszichológiai) elméletét tanuláselméleti szempontból, a klasszikus kondicionálás logikus következménye lehet a vizsgaszorongás (2. táblázat). A stressz, mint feltétlen inger összekapcsolódik a társítások révén (idői és helyzeti egybeesés) a vizsgaszituációval kapcsolatos kellemetlen, negatív élményekkel, képzetekkel, emlékekkel, gondolatokkal. Ez az alapélmény kiterjed más hasonló teljesítményhelyzetekre is, így feltételes válaszként beindítja a szubjektív és fiziológiás stresszfolyamatot, melynek végső következtetése, hogy „Minden vizsga stresszt jelent.” Ezt a jelenséget generalizációnak nevezzük. A tanulási folyamatban kialakult láncreflex révén az elsődleges inger, tehát az iskola, a tanterem, a tanár, a tanítási óra, majd a vizsgahelyzet gyors lefuttatása a „veszély” élményét váltja ki (Mező \& Mező, 2019 alapján). A „küzdj vagy menekülj” mechanizmus értelmében a tanuló a teljesítményhelyzettel szembeni szorongása „kezelésére” az elkerülést választhatja, és azokon a tanítási napokon, amikor kihívásra számíthat, távol marad az iskolától. A bevezetőben ismertetett láncreakció révén ez akár szomatikus tünetek produkálásában is manifesztálódhat. 
KÜLÖNLEGES BÁNÁSMÓD, VI. ÉVF. 2020/2.

2. táblázat. Tanuláselméleti példák a vizsgaszorongás alakulására az OxIPO-modell aspektusából (Forrás: Mezọ" és Merớ, 2019 alapján)

\begin{tabular}{|c|c|c|c|c|}
\hline Tanulás & $\begin{array}{l}\text { Orga- } \\
\text { nizá- } \\
\text { ció }\end{array}$ & Input & Process & Output \\
\hline $\begin{array}{l}\text { Klasszikus } \\
\text { kondicionáláson alapuló } \\
\text { vizsgaszorongás }\end{array}$ & \multirow{4}{*}{ 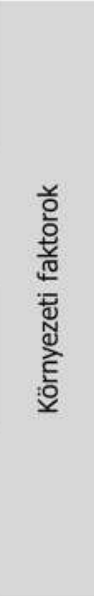 } & $\begin{array}{l}\text { Feltétlen inger: stressz + Feltételes } \\
\text { inger: vizsgával kapcsolatos negativ } \\
\text { élmény, képzet, emlék, gondolat }\end{array}$ & $\begin{array}{l}\text { Társítás: } \\
\text { Generalizáció: } \\
\text { Láncreflex: }\end{array}$ & $\begin{array}{l}\text { Feltételes v.: fiziológiai stressz } \\
\text { Minden vizsga stresszes } \\
\text { Iskola } \rightarrow \text { tanterem } \rightarrow \text { tanár } \rightarrow \text { tanóra } \\
\rightarrow \text { vizsgahelyzet } \rightarrow \text { VESZÉLY! }\end{array}$ \\
\hline $\begin{array}{l}\text { Operáns tanuláson } \\
\text { alapuló vizsgaszorongás }\end{array}$ & & $\begin{array}{l}\text { Vizsgahelyzet + büntetés adásnak } \\
\text { és/vagy jutalom megvonásnak az } \\
\text { átélése }\end{array}$ & $\begin{array}{l}\text { Behav.: ? } \\
\text { Neobehav.: } \\
\text { közvetitő } \\
\text { folyamatok }\end{array}$ & $\begin{array}{l}\text { A vizsgahelyzet kerülése } \\
\text { (büntetés és/vagy jutalom- } \\
\text { megvonás megelözése } \\
\text { érdekében), "betegségelőny" }\end{array}$ \\
\hline $\begin{array}{l}\text { Szociális tanuláson } \\
\text { alapuló vizsgaszorongás }\end{array}$ & & $\begin{array}{l}\text { Modell és megerősitésének ( } \mathrm{pl} \text {. } \\
\text { környezeti támogatás vagy kinevetés) } \\
\text { megfigyelése vizsgahelyzet előtt, } \\
\text { közben, után }\end{array}$ & $\begin{array}{l}\text { Vikariáció } \\
\text { (behelyettesítés) }\end{array}$ & $\begin{array}{l}\text { Modell szorongó vagy nem } \\
\text { szorongó viselkedésének } \\
\text { utánzása vagy elutasítása }\end{array}$ \\
\hline $\begin{array}{l}\text { Belátásos tanuláson } \\
\text { alapuló vizsgaszorongás }\end{array}$ & & $\begin{array}{l}\text { Korábbi megoldások kudarca (pl. } \\
\text { sikertelen tanulás)+latencia+belátás } \\
\text { (AHA élmény: a) jobb nem vizsgázni } \\
\text {, b) szorongó magatartással } \\
\text { manipulálható a környezet) }\end{array}$ & $\begin{array}{l}\text { Kognitív (és } \\
\text { emocionális) } \\
\text { feldolgozás }\end{array}$ & $\begin{array}{l}\text { A vizsga veszélyes/nem } \\
\text { veszélyes, illetve a tudatos } \\
\text { „pityergös” vizsgaviselkedésre } \\
\text { ösztönző kogníció kialakulása }\end{array}$ \\
\hline
\end{tabular}

\section{A vizsgálati módszer}

Maslow (1962) nyomán szintén logikus elméletvonulat a tanulási képességek és az azt befolyásoló tényezốk vizsgálata. Tevékenységének egyik célja volt, hogy feltérképezze, milyen módon lehetséges a képességek minél szélesebb körű és mélységú kibontakoztatása és érvényesülése. A tervezett vizsgálatban szintén a tanulmányi teljesítmény, előmenetel sikerességének prediktorait kívánjuk feltérképezni. Ehhez elsősorban a szorongásos tünetek, a szociális készségek színvonala, a kognitív képességek, illetve egyéb háttérváltozók (terhelő adat az anamnézisben, klinikai diagnózis (BNO10), gyógyszeres terápia, pedagógiai fejlesztés) azonosítása történik az egyes tanulók esetében. Az erre vonatkozó információk a Heves Megyei Tanulási Képességet Vizsgáló Szakértői és Rehabilitációs Bizottság irattárának áttekintésével kerültek feltárásra, szekunder adatgyüjtés formájában. A tanulóktól származó adatok közötti együttjárások, illetve alcsoportonkénti különbségvizsgálatok eredményeinek elemzése esetében a minta vizsgálati egysége a tanuló. A fóvizsgálati tervezett minta elemszáma 200 fő.
Jelen elôvizsgálati eljárás során 10, szorongásos tünetekkel is jellemezhető tanuló adatainak összehasonlítása, a lehetséges összefüggések feltárása történt. Az esetbemutatás szempontjai között az anamnézisben terhelő adat jelenléte, mint moderáló változó került feltérképezésre. Elsősorban pre-, peri- és posztnatális ártalmak, a szocioökonómiai státusz jelentősebb eltérései, környezeti traumák, illetve érzékszervi eltérések figyelembe vétele történt.

A klinikai szintú diagnózis a tünetek súlyosságát jelzi, gyermek- és ifjúságpszichiátriai/klinikai pszichológiai szempontot jelent. A gyógyszeres terápia a biológiai intervenció megvalósulását tartja számon. Ezek az információk a pszichés múködést befolyásoló, tehát pszichiátriai és/vagy neurológiai szinten hatást kifejtô gyógyszerszedésre vonatkoznak.

A szociális készségek színvonala abból a szempontból szükséges információ, hogy mennyiben jelent nehézséget a tanuló számára a kortársakkal, pedagógusokkal való interakciók során az együttmúködés illetve az önérvényesítés. Feltételezhető, hogy a szociális területen tapasztalt túlzott erő- 
feszítés a tanulmányi teljesítményre szánt kapacitásból vesz el időt, energiát. Erre vonatkozóan korábbi tanulmányok is közöltek eredményeket. Már 1983-ban megfogalmazták a szakemberek, hogy a szociális készségek hozzájárulnak az egyén azon képességéhez, hogy kapcsolatba lépjen másokkal erre alkalmas szituációkban, határozottan befolyásolják az alkalmazkodási készséget, a tanulmányi teljesítményt, és a hivatásbeli előrelépést (Argyle, 1983). Hátrányt jelent továbbá az iskolaévek kezdetén a szociális készségdeficit, mivel a gyerekeknek kapcsolatba kell lépniük számukra még idegen kortársakkal és felnőttekkel, és ez a kapcsolati háló folyamatosan növekszik (Ladd, Herald, \& Kochel, 2006). Az iskolai beilleszkedéshez tehát szükség van a szociális kompetenciák használatára, ami a társas szituációkban alkalmazott problémamegoldó készségben is megnyilvánul. Ahogyan a tanulók az idő előrehaladtával ezeket a szociális problémamegoldó készségeiket fokozatosan fejlesztik, jobb színvonalú alkalmazkodás figyelhető meg a viselkedésben és a tanulmányi területen egyaránt (Dubow, Tisak, Causey, Hryshko, \& Reid, 1991). A temperamentum egy fontos mediátor ebben a tekintetben, hiszen a félénkség és az impulzuskontroll (érzelem- és indulatszabályozás) szempontjából meghatározza az egyén reakcióinak minőségét és mennyiségét társas közegben, valamint közvetlen és közvetett módon a tanulmányi eredményeit.

A félénkség félelmi és frusztrációs reakcióként jelenik meg szokatlan, újszerú társas szituációkban. A félénk gyerekeknek igénye a másokkal való interakcióba lépés, azonban az átélt félelem és distressz arra ösztönzi őket, hogy elkerüljék a számukra még idegen szociális helyzeteket (Coplan, Prakash, O’Neil, \& Armer, 2004). Összességében elmondhatjuk, hogy az impulzuskontroll, tehát az önszabályozási készség fontos előrejelzője lehet az iskolai szociális és tanulmányi funkcionálásnak, mivel facilitálja a strukturált tantermi tanulást és az informális tanulást a kortársakkal és a tantermi kontextusban egyaránt (Walker, \& Henderson, 2012).
A szorongásjelzés vizsgálata az eseteknél a kutatás fó célkitǔzése, melynek tanulmányi sikerességgel való összefüggését a bevezető elméleti rész kiegészítéseként több tudományos eredménnyel lehet alátámasztani. Mind a tesztszorongás, mind a vonásszorongás rontja a tanulás minőségét, ami alacsonyabb színvonalú tanulmányi eredményekben nyilvánul meg (Chapell, Blanding, \& Silverstein, 2005).

Más vizsgálatok szerint azok az intervenciós törekvések, melyek a tanulással szembeni motivációhiányt, illetve a szorongás mértékét képesek csökkenteni, alkalmasak arra, hogy javítsák az elsőgenerációs egyetemi hallgatók tanulmányi eredményeit (Gaudier-Diaz, Sinisterra, \& Muscatell, 2019). A szorongás alapélménye a biztonság hiánya, és a biztonság megteremtésére való törekvés többletkapacitást foglalhat le a gyermek/serdüló pszichés múködésében. A figyelemelterelő illetve debilizáló szorongás tehát a tanórai koncentrációtól vonja el az energiát, illetve anticipátoros jellege miatt állandó készenlétet, előrevetített aggodalmat, ezáltal elkerülő magatartást indikálhat. A generalizációs folyamatok által a gyermek kudarckerülóvé válhat, ami az egyébként intakt, jól múködő funkcióit is gátolhatja.

$\mathrm{Az}$ intelligenciahányados az általános kognitív képességek színvonalát jelzi. A szakértói bizottság protokolljában szereplő tesztbattéria segítségével történt vizsgálatok eredményei alapján valósult meg az intelligenciaövezet szerinti besorolás. A három kategória meghatározása az átlaghoz való viszonyt fejezi ki: átlagos (IQ=80-110), átlag alatti (IQ>80), átlag feletti (IQ>110).

A fejlesztés megvalósulása a külső pedagógiai segítség elérhetőségét mutatja meg, a tanulmányi hátrányok leküzdése, az előmenetel javítása céljából. A tanulmányi elómenetel a pedagógiai szintű beavatkozás eredményességét, illetve feltételezhetően a szociális készségek és a szorongásos tünetek jelenlétének befolyását összegzi.

Erről a rendelkezésre álló dokumentációból a legutóbbi szakértôi vizsgálat mellékleteként csatolt pedagógiai jellemzés szolgáltat információt. 
3. táblázat. A szorongás, a sqociális készségek és egyéb háttértényezők összefüggése a tanulmányi elömenetellel (Forrás: Szeræő́)

\begin{tabular}{|c|c|c|c|c|c|c|c|c|c|c|}
\hline Eset & Nem & Életkor & Anamnézis & BNO & Gyógyszer & $\begin{array}{l}\text { Szociális } \\
\text { készség }\end{array}$ & Szorongás & IQ & Fejlesztés & $\begin{array}{l}\text { Tanulmányi } \\
\text { elömenetel }\end{array}$ \\
\hline 1. & Fiú & 16 & - & + & - & + & + & Átlag alatt & + & Nehézség \\
\hline 2. & Lány & $9 ; 11$ & - & - & - & - & + & Átlag alatt & - & Nehézség \\
\hline 3. & Lány & $15 ; 10$ & Gyermekotthon & + & + & + & + & Átlag alatt & + & Nehézség \\
\hline 4. & Fiú & $16 ; 1$ & - & + & - & + & + & Átlag alatt & + & Nehézség \\
\hline 5. & Fiú & 17 & Látászavar & + & - & + & + & Átlag alatt & + & Nehézség \\
\hline 6. & Fiú & 12 & $\begin{array}{l}\text { Gyermekotthon; } \\
\text { Szomatikus } \\
\text { eltérés }\end{array}$ & + & + & + & + & Átlag alatt & + & Sikeres \\
\hline 7. & Lány & 11 & Perinatális & + & + & + & + & Átlag alatt & + & Sikeres \\
\hline 8. & Fiú & $10 ; 2$ & Nyelvi elmaradás & + & + & + & + & Átlag alatt & + & Nehézség \\
\hline 9. & Lány & 16 & $\begin{array}{l}\text { Szociális hátrány; } \\
\text { Prenatális ártalom }\end{array}$ & + & - & + & + & Átlagos & + & Nehézség \\
\hline 10. & Lány & $11 ; 5$ & $\begin{array}{l}\text { Prenatális; agyi } \\
\text { anatómiaeltérés }\end{array}$ & + & - & + & + & Átlagos & + & Nehézség \\
\hline
\end{tabular}

\section{Eredmények}

Az elővizsgálat megfigyelései alapján néhány egyszerủ összefüggés vonható le a 10 tanuló adatai alapján. A nemek tekintetében nem mutatkozott megfigyelhető eltérés a szociális készségek szintje, a szorongás jelenléte, valamint a tanulmányi előmenetel tekintetében. A klinikai szintű problémával küzdő, tehát BNO-kóddal is rendelkező tanulók minden esetében megvalósult fejlesztés. A szociális készségdeficit és a szorongás szinte valamennyi esetében együtt jár. Két tanuló esetében a gyógyszeres kezelés a tanulmányi előmenetelt előnyösen befolyásolta, a szociális készségek gyengébb színvonala valamint a szorongás ellenére is. Az átlagosnál alacsonyabb intelligenciahányados, illetve a szociális készségdeficit és a szorongás együttjárása a fejlesztés ellenére is nehézséget okozott a tanulmányi előmenetelben. Végül az anamnézisben terhelő adat jelenléte nem tekinthető jelentős moderáló tényezőnek a változók tekintetében.

\section{Összegzés}

A pedagógusi tevékenység egyik alapvető célkitűzése a képességek és a személyiség minél szélesebb körű és mélységú fejlesztése a közoktatási intézmények hatáskörében. Minél gazdagabb ismeretekkel rendelkezünk a tanulók általános és specifikus vonásait illetôen, annál hatékonyabb munka végezhető. Jelen tanulmány és az előirányzott vizsgálat azzal kíván hozzájárulni ehhez a folyamathoz, hogy ráirányítja a figyelmet a lehetséges moderáló tényezők szerepére, elsősorban a szorongásos tünetegyüttes, a szociális készségek és a kognitív képességek összefüggéseire. A különböző szakmaterületek szoros együttmúködése szükséges ahhoz, hogy a gyermekek, serdülők minél célirányosabb, személyre szabottabb segítséget kapjanak pszichés és tanulmányi problémáik kapcsán egyaránt.

A szorongásos zavarok igen gyakori előfordulású kórképek, korai indulás jellemző, és gyakran egyéb 
pszichés problémákkal társulnak, valamint felnôttkorra is átörökíthetők. Megjelenésükre kritikus életesemények kapcsán fokozottan kell számítani, hiszen a gyermek kialakult alapbiztonságát zavarják meg a változások. A krízisek tehát rizikót jelentenek a szorongás kialakulására. Fontos azonban, hogy a környezet hajlamos lehet alacsonyabb küszöbbel viszonyulni az érintett felé, így azonban betegségtudatot kelthetünk, ami előnytelenül befolyásolhatja a megoldáskeresést. A pedagógusi visszajelző rendszer azonban hatékony lehet abban, hogy a gyermek/fiatal a tanuló szerepében stabilan legyen jelen, erôsségeit használni tudja, és megküzdési készsége aktív maradjon. A gyermek alapbiztonságához a megfelelő keretrendszer, a kiszámíthatóság, a hiteles értékelések nagyban hozzájárulhatnak.

A fizikai tünetek, betegségek figyelemfelhívó szerepének, a test segítségkérő „kiáltásának” felismerése szintén egy útja annak, hogy a tanuló valódi problémái feltárásra kerülhessenek. Az immunrendszer tartós stressz hatására nem nyújt kelló védelmet, ami sérülékennyé teszi a szervezetet különféle ártalmakkal szemben. Evolúciós szempontból szintén hasznos információ, hogy a túlzott érzékenység miért lehet adaptív a szorongó gyermek számára. Minden esetben fel kell készíteni a fiatalt a személyes megküzdésre, természetesen a megfelelő mértékủ külső segítségnyújtás mellett. Ha sikerül megtapasztalnia, hogy képes hatékonyan befolyással lenni az események és saját intrapszichés múködése fölött, hozzásegítjük az énhatékonyság megtapasztalásához. Ezáltal a tanult tehetetlenség bénító hatása is megakadályozható.

Ha szorongás tünetei észlelhetők az egyén problémáinak kapcsán, szükséges a szociális készségek színvonalának vizsgálata is, hiszen utóbbiak fejlesztése jelentősen hozzájárulhat mind a pszichés tünetek, mind a tanulmányi eredmények hatékony kezeléséhez, javításához. A gyógyszeres terápia szükségességének felülvizsgálata érdekében a diagnosztikus vizsgálatok során gyermek pszichiáter szakorvos felkeresése is célszerú lehet. A szülők gyakran mereven elzárkóznak a terápiás ellátás gyógyszeres készítménnyel történő kiegészítésétől. Valóban célszerű megfelelő körültekintéssel dönteni a farmakoterápia választása kapcsán, azonban nem feltétlenül szükséges hosszú távú gyógyszeres kezelésre berendezkedni. Amennyiben a szorongásos zavar pszichoterápiás ellátása akadályozva van, tehát a megfelelő végzettségú szakember, a kialakult terápiás kapcsolat és a protokoll szerint hatékony módszer ellenére sem sikerül eredményt elérni, átmenetileg megfontolandó a pszichofarmakon alkalmazása.

\section{Köszönetnyilvánítás}

A szerző köszönetét fejezi ki az Eszterházy Károly Egyetem felé az EFOP-3.6.1-16-201600001 „Kutatási kapacitások és szolgáltatások komplex fejlesztése az Eszterházy Károly Egyetemen" című projektben való részvétel lehetővé tételéért.

\section{Irodalom}

Angold, A., Costello, E.J., \& Erkanli, A. (1999). Comorbidity. Journal of Child Psychology and Psychiatry, 40, 57-87. DOI: 10.1111/1469$\underline{7610.00424}$

Argyle, M. (1983). The psychology of interpersonal behavior. Harmondsworth, England: Penguin.

Beck, A. T. \& Emery G. (1999). A szorongásos zavarok és fóbiák kognitiv szemlélete. Budapest: Animula Kiadó.

Bereczkei T. (2003). Evolúciós pszichológia. Budapest: Osiris Kiadó.

Biederman, J., Wilens, T., Mick, E., Faraone, S.V., Weber, W., Curtis, S. et al. (1997). Is ADHD a risk factor for psychoactive substance use disorders? Findings from a fouryear prospective follow-up study. Journal of the American Academy of Child and 
Adolescent Psychiatry, 36, 21-29. DOI: $10.1097 /$ 00004583-199701000-00013

Birmaher, B., Ryan, N.D., Williamson, D.E., Brent, D.A., Kaufman, J., Dahl, R.E. \& Nelson, B. (1996). Childhood and adolescent depression: A review of the past 10 years. Part I. Journal of the American Academy of Child and Adolescent Psychiatry, 35, 1427- 1439. DOI: 10.1097 / $00004583-$ 199611000-00011

BNO-10 Zsebkönyv. DSM-IV-TR meghatározásokkal. Budapest: Animula. 2004.

Bowlby, J. (1973). Attachment and loss, Vol. 2: Separation. Anger and anxiety. London: Pimlico.

Cannon, W.B. (1929). Bodily Changes in Pain, Hunger, Fear and Rage: An Account of Recent Researches into the Functions of Emotional Excitement. 2nd ed. New York, Appleton Century-Crofts.

Chapell, M.S., Blanding, Z.B. \& Silverstein, M.E. (2005). Test anxiety and academic performance in undergraduate and graduate students. Journal of Educational Psychology, 97 (2), 268-274. DOI: 10.1037/0022-0663.97.2.268

Coplan, R.J., Prakash, K., O’Neil, K. \& Armer, M. (2004). Do you „want” to play? Distinguishing between conflicted shyness and social disinterest in early childhood. Developmental Psychology. 40, 244-258. DOI: 10.1037 / 0012$\underline{1649.40 .2 .244}$

Costello, E.J., Egger, H.L. \& Angold, A. (2005). The developmental epidemiology of anxiety disorders: phenomenology, prevalence, and comorbidity. Child and Adolescent Psychiatric Clinics of North America, 14, 631-648. DOI: $10.1016 /$ j.chc.2005.06.003

Donovan, C. L., \& Spence, S. H. (2000). Prevention of childhood anxiety disorders. Clinical Psychology Review, 20 (4), 509-531. DOI: $10.1016 /$ s0272-7358 (99) 00040-9

American Psychiatric Association: Diagnostic and Statistical Manual of Mental Disorders Fourth Edition (DSM-IV). Washington, DC, 1994.
DSM-5 referencia-kézikönyv a DSM-5 diagnosztikai kritériumaihoz. Oriold és Társai, Budapest, 2013.

Dubow, E.F., Tisak, J., Causey, D., Hryshko, A. \& Reid, G. (1991). A two-year longitudinal study of stressful life events, social support, and social problem-solving skills: Contributions to children's behavioral and academic adjustment. Child Development, 62, 583-599. DOI: $10.2307 /$ $\underline{1131133}$

Eley, T.C. \& Stevenson, J. (1999) Exploring the covariation between anxiety and depresssive symptoms: a genetic analysis of the effects of age and sex. Journal of Child Psychology and Psychiatry, 40, 1273-1282. DOI: $10.1111 / 1469-7610.00543$

Essau, C.A., Conradt, J. \& Petermann, F. (2002) Course and outcome of anxiety disorders in adolescents. Journal of Anxiety Disorders, 16, 67-81. DOI: 10.1016 / s0887-6185 (01) 00091-3

Garber, J., \& Weersing, V.R. (2010). Comorbidity of anxiety and depression in youth: Implications for treatment and prevention. Clinical Psychology, 17, 293-306. DOI: 10.1111 / j.14682850.2010.01221.x

Gaudier-Diaz, M.M., Sinisterra, M., \& Muscatell, K.A. (2019). Motivation, belongingness, and anxiety in neuroscience undergraduates: Emphasizing first-generation college students. The Journal of Undergraduate Neuroscience Education, 17 (2), A145-A152.

George, D.T., Nutt, D.J., Dwyer, B.A. \& Linnoila, M. (1990) Alcoholism and panic disorder: is the comorbidity more than coincidence? Acta Psychiatrica Scandinavica, 81, 97-107. DOI:10.1111 / i.16000447.1990.tb06460.x

Gilbert, P. (1998). Evolutionary psychopathology: Why isn't the mind designed better than it is? British Journal of Medical Psychology, 71, 353-373. DOI:10.1111/j.2044-8341.1998.tb00998.x 
Goodman, R. \& Scott, S. (1997) Child psychiatry. Oxford: Blackwell Science.

Holmes, T. H. \& Rahe, R. H. (1967). The social readjustment rating scale. Joumal of Psychosomatic Research, 11 (2), 213-221. DOI:10.1016/00223999(67)90010-4

Irwin, M., Hauger, R.L., Jones, L., Provencio, M. \& Britton, K.T. (1990). Symapthetic nervous system mediates central corticontropin -releasing factor induced suppression of natural killer cytotoxicity. Journal of Pharmacology and Experimental Therapeutics, 255, 101-107.

Keller, M.B., Lavori, P. Wunder, J., Beardslee, W.R., Schwartz, C.E. \& Roth, J. (1992). Chronic course of anxiety disorders in children and adolescents. Journal of the American Academy of Cbild and Adolescent Psychiatry, 31, 595-599. DOI: 10.1097 / 00004583$\underline{199207000-00003}$

Kessler, R.C., Avenevoli, S., \& Merikangas, K.R. (2001). Mood disorders in children and adolescents: An epidemiologic perspective. Biological Psychiaty, 49, 1002-1014. DOI: $10.1016 /$ $\underline{\text { s0006-3223 (01) 01129-5 }}$

Kushner, M.G., Abrams, K. \& Borchardt, C. (2000). The relationships between anxiety disorders and alcohol use disorders: a review of major perspectives and findings. Clinical Psychology Review, 20, 149-171.

Ladd, G.W., Herald, S.L. \& Kochel, K.P. (2006). School Readiness: Are there social prerequisites? Early Education and Development, 17, 115150. DOI: 10.1016 / s0272-7358 (99) 00027-6

Last, C.G., Hansen, C. \& Franco, N. (1997). Anxious children in adulthood: a prospective study of adjustment. Journal of the American Academy of Cbild and Adolescent Psychiatry, 36, 645-652. DOI: 10.1097 / 00004583-199705000-00015

Lopez, B., Turner, R., J. \& Saavedra, L.M. (2005). Anxiety and risk for substance dependence among late adolescents/young adults. Journal of Anxiety Disorders, 19, 275-294. DOI: 10.1016 / i.janxdis.2004.03.001

Marks, I.M. (1969). Fears and Phobias. New York: Academic Press.

Maslow, A.H. (1962). Toward a psychology of being. Princeton, NJ: Van Nostrand.

Maslow, A.H. (1970). Motivation and personality. (Rev.ed.). New York: Harper \& Row.

McGue, M. (1994). Genes, environment, and the etiology of alcoholism. In: Zucker, R., Boyd, G. \& Howard, J. (Eds.) Development of alcohol problems: exploring the biopsychosocial matrix. Monograph No. 26. (pp. 140.) Bethesda, MD: National Institute on Alcohol Abuse and Alcoholism.

McGuire, M.T. \& Troisi, A. (1998). Darwinian Psychiatry. New York: Oxford Press.

Mező F. \& Mező K. (2019). Az OxIPO-modell az interdiszciplináris kutatások egy lehetséges értelmezési kerete. OxIPO - interdiszciplináris tudományos folyoirat, 2019/1, 9-21. DOI: 10.35405/OXIPO.2019.1.9

Mirin, S.M. \& Weiss, R.D. (1991). Substance abuse and mental health. In: Frances, R.J., Miller, S.I. (Eds.). Clinical textbook of addictive behaviour. New York, NY: Guilford Press. 271-298.

Nagy, P. (2015). Szorongásos zavarok. In: Balázs J. \& Miklósi M. (szerk.). A gyermek- és ifjúkor pszichés qavarainak tankönyve. Budapest: Semmelweis Kiadó. 101-109.

Nesse, R. M. (1987). An evolutionary perspective on panic disorder and agoraphobia. Ethology and Sociobiology, 8, 73-83. DOI:10.1016/0162$\underline{3095(87) 90020-3}$

Nesse, R.M. (1990). Evolutionary explanations of emotions. Human Nature, 1, 261-289. DOI: 10.1007 / BF02733986

Nesse, R.M. (1999). Proximate and evolutionary studies of anxiety, stress, and depression: Synergy at the interface. Neuroscience and Biobehavioral 
Review, 23, 895-903. DOI:10.1016 / S0149-7634 (99) 00023-8

Paykel, E.S. (1991). Stress and life events. In: Davidson, L., Linnoila, M. (Eds.). Risk factors for youth suicide. New York, Hemisphere.

Pine, D.S., Cohen, P., Gurley, D., Brook, J. \& Ma, Y. (1998). The risk for early-adulthood anxiety and depressive disorders in adolescents with anxiety and depressive disorders. Archives of General Psychiatry, 55, 56-64. DOI:10.1001 / archpsyc.55.1.56

Purebl, Gy. (2016). Szív- és érrendszeri halálozás a személyiség és pszichés tünetek tükrében. Előadás: Klinikai és mentálhigiéniai szakpszichológusi szakképzés. Mentálhigiéné, egészséglélektan és alkalmazott területek. Budapest, 2016. október 18.

Rao, U., Ryan, N.D., Birmaher, B., Dahl, R.E., Williamson, D.E., Kaufman, J. \& Nelson, B. (1995). Unipolar depression in adolescents: Clinical outcome in adulthood. Journal of the American Academy of Child and Adolescent Psychiatry, 34, 566-578. DOI:10.1097 / 00004583199505000-00009

Scholten, W.D., Batelaan, N. M., van Balkom, A.J.L.M., Wjh. Penninx , B., Smit, J.H., \& van Oppen, P. (2013). Recurrence of anxiety disorders and its predictors. Journal of Affective Disorders, 147, 180-185. DOI: $10.1016 /$ i.jad $\underline{2012.10 .031}$
Stowell, J.A. (1991). Dual diagnosis issues. Psychiatric Annals, 21, 98-104.

Tringer L. \& Veér A. (1977). Egyes élethelyzetek stressz-hatásainak elemzése. Ideggyógyászati S zemle, 30/33, 3-32.

Vetró Á. (1999). Gyermek-és ifjúságbszichiátria, mentálhigiéné. Szeged: JGyTF Kiadó.

Walker, O.L., \& Henderson, H.A. (2012). Temperament and social problem solving competence in preschool: Influences on academic skills in early elementary school. Social Development, 21 (4), 761-779. DOI:10.1111 / j.14679507.2011.00653.x

WHO (2020) http://www.euro.who.int/en/healthtopics/noncommunicable-diseases/mentalhealth/news/news/2012/10/depression-ineurope/depression-in-europe-facts-and-figures Letöltés ideje: 2020.02.25.

Wittchen, H.-U., Essau, C.A. \& Krieg, C. (1991). Anxiety disorders: similarities and differences of treated and untreated groups. British Journal of Psychiatry, 159, 23-33.

Zavos, H.M.S., Rijsdijk, F.V., Gregory, A.M. \& Eley, T.C. (2010). Genetic influences on the cognitive biases associated with anxiety and depression symptoms in adolescents. Journal of Affective Disorders, 124, 45-53. DOI:10.1016/i.jad.2009.10.030 